\title{
Between town and country: shifting identity and migrant youth in Uganda*
}

\author{
Caroline Barratt \\ School of Health and Human Sciences, University of Essex, Wivenhoe \\ Park, Colchester $\mathrm{CO}_{4}{ }_{3} \mathrm{SQ}$, United Kingdom \\ Email: barrattc@essex.ac.uk \\ Martin Mbonye \\ MRC/UVRI Uganda Research Unit on AIDS, PO Box 49, Entebbe, \\ Uganda
}

Email: martin.mbonye@mrcuganda.org

and

JANET SEeley

School of International Development, University of East Anglia, Norwich $\mathrm{NR}_{4} 7 \mathrm{TJ}, \mathrm{UK}, \mathrm{MRC/UVRI}$ Uganda Research Unit on AIDS, Entebbe, Uganda and London School of Hygiene and Tropical Medicine, Keppel Street, London WCIE 7 HT, United Kingdom

Email: j.seeley@uea.ac.uk

\section{A B S T R A C T}

In Uganda, as in many other African countries, increasing numbers of $15^{-24}$ year olds are migrating to urban areas to look for work and educational opportunities. We explore the shifting sense of identity amongst youth migrants

* We are grateful to Dr Brent Wolff, who set up and led the larger study from which the data for this paper have been extracted. We thank the Medical Research Council (UK) for funding the study, the interviewers for their work in collecting and translating the data, and the participants for giving the team their time and information. We are grateful to Dr Catherine Locke for her very insightful comments on an earlier version of this paper. We acknowledge our reviewers, whose very insightful comments helped to develop the framing and debate within this paper. 
in Uganda as they struggle to reconcile the differences in social norms between the rural settings in which they are brought up and the urban environment in which they now live. The experience of migration significantly impacts on the transition from youths to adults by influencing their perception of their own identity as well as the expectations of society. Young people often hold conflicting views of their rural and urban experiences, suggesting that understanding rural and urban realities as distinct entities does not reflect the complex relationship, and possible confusion, of the migrant experience. In contrast to existing literature on migrant identities, which has tended to focus on the identity shift experienced by adult transnational migrants, this reveals the particular challenges faced by youth migrants whose adult self is not yet formed.

The relationship between identity and migration is usually discussed in relation to transnational migration and typically in connection to the experience of adults. The experience of children and youth is often overlooked as they are considered passive dependents and not active agents in the migration process. Recent ethnographic research with youth migrants by Thorsen (2006) and Hashim and Thorsen (2011) shows young people to be independent social actors who make the decision to migrate based on a variety of social as well as economic factors. They show that the experience of migration has a significant impact on the identity of young people, and in some contexts may have become a rite of passage into adulthood (Thorsen 2006: 99). In this article, we explore the experience of rural-urban youth migrants in two towns in Uganda, discuss their experiences of town life, and consider the impact of migration on their sense of their own identity.

Uganda has the youngest population in the world (World Bank 2008). According to that report, $83 \%$ of young people aged $15^{-24}$ years are unemployed, and many of these are urban migrants. The World Bank authors caution that this youthful population could be a source of crime and instability. Blum and Nelson-Mmari (2004) and Buvé et al. (2002), among other commentators, raise concerns about the impact on young people's health and well-being, particularly their sexual health. By increasing our understanding of the experience of young migrants we may be better placed to identify the services from which they would benefit, and how they can be assisted in accessing the economic possibilities of city life as opposed to being exposed to its inherent risks.

Over the last decade, increased attention has been paid to the migration experience of young people, particularly in the North, where 
interest in the migrant's experience has been coupled with concern about the future of rural areas as an ageing population is left behind (Lowe \& Speakman 2006; Montgomery et al. 2003). Research on youth migration in sub-Saharan Africa has often focused on the volume of migration, and the impact of movement on overstretched resources in urban areas, as well as risks to health (Boadi \& Kuitunen 2005; Coetzee \& Schneider 1996; Garenne 2010). Thorsen (2006) and Hashim and Thorsen (2011) highlight how rural-urban migration plays a significant role in the transition from young person to adulthood. Thorsen (2006: 99) notes: 'The gradual integration into the adult social world ... shapes children's and young people's perception of themselves, and consequently where they seek to position themselves in relation to their family and friends.' This paper therefore explores what might be described as an 'identity crossroads': we are concerned with how moving from a rural to an urban area affects young people's identity as they move from youth to adulthood.

\section{UNDERSTANDING R URAL-URBAN MIGRATION}

Rural-urban migration has long been a livelihood strategy used by households in the developing world to increase household incomes. Even in the 1980s, during the time of the debt crisis and structural adjustment when living standards in cities declined significantly, urban growth still continued, bolstered by many young people in search of work. The influential work of Harris and Todaro (1970) proposed that even though employment opportunities and earning potential could essentially be quite low in some urban settings, people were still drawn there by expectation of higher incomes over their lifetime. However, Katz and Stark (1986) described how decisions about whether and where to migrate are based on a variety of factors such as kinship and friendship ties, but are also influenced, as Byerlee (1974: 551) suggested, by 'such critical questions as the determinants of rural incomes, the role of rural education and information and noneconomic variables relating to the rural social system' (italics in the original). Indeed, this rural as well as urban orientation may help us to understand why migration takes place even where there is no obvious economic gain or possibly even an economic loss. Herrin et al. (2009), in their study of migration and wealth accumulation in Uganda, found that the more moves a migrant made in search of employment the less wealth there was per household member, each move fuelled by the hope of success; and the perceived success of others as well as the lack of opportunities 
in the rural area, is a theme explored in other research (Bertaux-Wiame 1979; Gardner 1993 for example). Migration may also have social as well as economic importance. Thorsen (2006) emphasises that migration to urban areas in Burkino Faso was understood not just in economic terms but as a way in which young people could increase their social status and prepare for adult responsibilities. The association of urban areas with development and education may also contribute to a rise in the social status of those who migrate. Returning to the village was seen as a last resort for those unable to make money in the town, despite concerns over the safety of the morals of those who did migrate (Cheney 2007).

The importance of a rural as well as an urban orientation for the migrant has long been emphasised by researchers of urbanisation in Africa (Hart 1971; Van Velsen 1960), although this was assumed to be 'just a passing phase' (Gugler 2002: 22) in development. Recent research has shown that this is not so; the relationship between urban migrants and their rural connections remains strong (Englund 2002; Gugler 2002). Gugler (2002: 22) states that 'many urban dwellers in Africa south of the Sahara are firmly rooted in a rural context'. They do not simply become 'urban' because they move to the city; for many home will still be defined by the rural residence of their parents or wider family group. Furthermore, Cheney (2007) emphasises the importance of 'the village' in the identity of urban youth in Uganda, noting that it provides a focus for ethnicity and in turn national identity. Yet despite the importance of rural roots, in many different settings, Jones (1999) notes that migrants construct different 'socio-spatial identities' adapted to changing circumstances and reference groups, built for example around age, gender, ethnicity and education.

\section{Migration and identity}

Previous research on migrant identities has largely focused on crossborder migrants and how they adjust to life in a new country. Theoretically much of this work has been based on acculturation theory (Padilla \& Perez 2003), which is concerned with how people adapt to their new contexts, and social identity theory (Hogg \& Abrams 1988), focusing on how people formulate their identity through association with social 'in-groups'. Rural-urban migration has not been subject to the same kind of focus with regard to people's changing identities. Instead it has often been studied in the context of health and livelihoods research, and little attention has been given to the impact of the incountry migration experience on individuals' sense of themselves; this is 
particularly so for adolescent migrants who are gaining independence from their parents while beginning to make decisions for themselves (Kloep et al. 2003). Moving from rural to urban areas can be a massive change for youthful migrants, as they are expected to cope in a substantially different social, moral and economic milieu (Goodenow \& Espin 1993). Thorsen (2006) observes that rural-urban migration has now become a rite of passage, especially for young men in Burkina Faso. The high expectations that frequently accompany rural to urban migration, on the part of both migrants and their families, may put greater pressure on them to show that they can flourish in their new environment.

The challenges of identity assimilation for individuals who migrate from rural to urban areas in their own country are compounded by the tension between rural life at home and the realities of an urban existence. In the context of internal migration, migrants' relatively close proximity to their rural roots may support a sense of identity which incorporates a new aspect that enables them to accept and function in their new setting, but also enables them to return home and honour the commitments and family ties that they have there (Englund 2002; Molyneux et al. 2002). It is not that internal migrants are switching between two distinct identities, but that they find a sense of identity that enables them to incorporate their idea of themselves as both urban and rural residents, as well as other identities they may hold. As Gabriel (2006: 43) found in her study of young migrants from Tasmania, 'young people drew on partial identities in different contexts in order to, at times, downplay emerging differences between themselves and their families and alternately to establish new points of connection'.

\section{Youth and identity}

Adolescence is itself a time of change, as young people establish an individual, adult, identity. Erikson (1968) describes adolescence as a time when the identifications we make as children, based on our own family, are tested and altered as we start to engage in the external social world. He notes: 'The adolescence process ... is conclusively complete only when the individual has subordinated his childhood identifications to a new kind of identification, achieved in absorbing sociability and in competitive apprenticeship with and among his age mates' (ibid:: 155 ). Young migrants may find many possible age mates, from different backgrounds to their own, in a new urban setting which may provide opportunities to explore new, fluid identities, as they strive to fit into the 
new place. Therefore, we can expect that for young adolescents the new social worlds which they engage with through migration will impact on their identity formation at a pivotal time in their development, and that this impact may be greater than for adults whose identities are more firmly developed.

A study of youth transition in Uganda (Weeks 1973) emphasised the cultural specificity of the transition to adulthood and the differences between tribes. However, common features of this transition included land-ownership (to demonstrate independence from parents), marriage, having children, as well as developing an 'adult intellect' which enables them to take part in family and clan decisions. Blum (2007) emphasises that rapid development in sub-Saharan Africa has been very destabilising for the youth themselves, as well as for how youth is defined, and specifically mentions rural-urban migration as a feature of the socially disruptive forces that have resulted in a deterioration of traditional social structures. Rural-urban migration may be a useful tool in acquiring capital, both human and economic, and as a result may accelerate this transition to adulthood. However, rapid social change in Africa means that the boundaries of youth and adulthood are becoming increasingly contested, and therefore the sense of identity amongst youth is already culturally blurred and may be increasingly so once they migrate away from home.

\section{Researching migration}

Exploring the lived experience of migrants is challenging. Research in a number of different settings has shown that life-history and personal narrative techniques have considerable potential for revealing migration experiences (Bertaux-Wiame 1979; Gardner 1993; Miles \& Crush 1993, among others). The development of a biographical approach to youth migration has provided valuable insights into understanding the 'complex and multi-layered nature of individual migration decisions among young people and changes in migration pathways over time' (Gabriel 2006: 34). Such narratives of experience are socially constructed, shaped by gender and other social relations. They are not simply what Miles and Crush (1993) term uncontaminated facts about the past. The stories are told to someone, and who that person is and the site of the telling influence the content and the ways in which the story is told. Bourdieu (2000: 300 ) talks of the biographical illusion because the storyteller 'is always partially motivated by a concern to give meaning, to rationalise, to show the inherent logic, both for the past and for the 
future'. He used 'illusion' not to mean falsity but to suggest that as individuals we actively construct the stories that we tell about our lives, and that these are inherently subjective, influenced by time, place and changing perspectives, and thus provide a window on identity and its performance. In this paper, we listened to the way in which young people describe who they are, what they do and what they hope for, in order to explore the plural identities of young men and women as they find a place to belong both 'at home' in the rural place they moved from, and in the town.

\section{Background and context}

The data on which this paper is based were collected in the course of a study on sexual health and mobility among urban youth in Uganda, between 2003 and 2005. The research sought to explore the sexual health concerns, risk behaviours, service and information needs among youths in urban slum settings; but during the course of that data collection the young people also provided a considerable amount of biographical information on which we have drawn for this paper. The two urban areas selected for this study were chosen because they were key entry points or points of attraction for rural youth hoping to earn a better living in a more developed setting, sometimes as a temporary stopover before proceeding to larger towns or the capital city, Kampala. These places were also close to their rural homes and many young people already had relatives there.

\section{Methods}

This paper is based on data collected during thirty-nine in-depth interviews with migrant youths (eighteen women and twenty-one men). As part of the main study mentioned above, two consecutive questionnaire surveys with about 300 unmarried youths aged fifteen to twenty-five were conducted in March 2004 and May 2004 in the two study areas. During the second survey, recently migrated youths (those who reported having arrived between six and eighteen months earlier) were invited to participate in in-depth interviews. We considered this period to be adequate, since at six months youth were in the early days of experiencing urban life while by eighteen months they could still remember some of their earlier experiences but could also give us the mid- to long-term perspective. For youths below eighteen years, parental/guardian permission was secured for those in the residential 
sample, while for those in the occupational sample the employers were requested to give consent. Once they had agreed, written informed consent from the participants themselves was secured. Interviews were typically conducted at the homes of the participants, although some were conducted at a neutral place selected by the youths themselves.

Interviews were conducted in Luganda by seven trained and experienced (three male and four female) interviewers who were familiar with the two areas. All the interviewers were familiar with the local language which was used in the in-depth interviews. Although the interviewers were in most cases older than the youths, this did not appear to affect the flow of information, since a strong rapport had already been created through previous data collection. The interviewers also had experience of, and some indeed resided in, rural settings similar to those from which the youths came. All interviews were taperecorded, with the permission of the respondent, and transcribed and translated prior to carrying out manual thematic content analysis. Interviews lasted between one and two hours. Ethical clearance was secured from the Uganda Virus Research Institute Science and Ethics committee, as well as the Uganda National Council for Science and Technology.

Having provided the background for this research we now move on to consider how the young rural-urban migrants experienced the shift from village to town life and discuss the issues of identity that arise.

\section{F I N D I N G S}

We first discuss two cases in depth. By doing this we go beyond identifying the normative performances of rural, migrant and urban youth, and common tensions between them, to examine the unfolding process of identity construction and management and how this plays into and in turn is shaped by the youth's experience of migration.

\section{Noah $^{1}$}

Noah was a seventeen-year-old male who grew up in a village called Kitolo. At the time of the interview, he still considered Kitolo to be his home. Until he was three or four he lived elsewhere with his mother and his stepfather. His real father had died of AIDS-related illness before Noah was born. When his mother became sick due to AIDS she returned to her mother's village and took Noah to live with his paternal grandfather in Kitolo. Noah's mother died when he was five, followed 
a few years later by his stepfather. Noah was brought up by his grandparents. He has one older sister from his mother's relationship with his father. She was studying in Kampala.

Noah was sixteen when he was brought to Mputu by his grandparent to train as a welder. He had been there a year at the time of interview, and during this time had been working as a trainee at the same establishment. He had come because his relatives felt he was underperforming at school. He said: 'So I decided to start doing these jobs and pestered my grandparent to bring me here.' For five months before coming to Mputu, after leaving primary school, Noah was employed to dig other people's land. He describes this work as physically difficult and poorly paid: he would get paid, and then buy food and the money would be gone. In town he gets paid much more and is still learning, which he was not while digging. Sometimes in the village he had found that no one wanted to employ him, making it difficult for him to earn money. At that time Noah also reared animals - rabbits, chickens and pigs. The rabbits didn't have a market and were eaten mostly at home, the chickens got stolen and the pigs were a problem as they took a long time to mature and this made it difficult for him to earn a living. This was his comment about village life: 'When I was in the village, I could not buy myself something [to] put on or even to see it, admire it. Everything was done for me and this is why I wanted to come to town: because I get money and buy anything I feel like.'

Noah's story is quite typical of those collected during the study, the inability of his family to continue paying for his education and his frustration with work in the village. His description of how things have changed clearly expresses his boosted esteem since moving to Mputu: 'Well, they mostly admire it [urban life] for bringing their children to learn vocational jobs. Also, when I go back [to the village] I am always smartly dressed and changed compared to how I used to be. There is also one [a young person from the village] [that] I brought in here [the town] recently whose guardians admired me and decided to bring him here so as to learn jobs.' However, despite this apparent preference for town life, he expresses frustration at not being able to spend time in the village and to see all the people he would wish to: 'The bad thing is that if I go in the village, I don't take long there to see many people. I only spend one day home of which I come back in the evening so I get less information from there.'

Before he moved to Mputu, people in the village, adults and older children, had promised him that it was a good place so he was very keen to come. When asked about what they had said was good about the town 
he says that they had told him that the place was 'interesting', that there were things that are not found in the village. When asked what things in particular he becomes coy and laughs mentioning only music. He then goes on, 'you can go and watch films and different musicians but in the village you have nothing you can watch'. His responses indicate that he heard things about town life that it seems he was embarrassed to relate to the interviewer.

Noah reported several problems he had on coming to the town: 'The problems I encountered [at] first-I was used to eating much in the village but here we only had one meal, I could no longer see a sugar cane which I used to see in the village and maybe the clothing and beddings for what I had in the village was not enough.' He had carried his bedding from the village but described it as 'old and shaming'. Some of the things that Noah had expected to find in the town did not materialise. He describes how the music was much less common than he had expected. He first lived in accommodation provided by his employer but then moved to a different place where his grandfather paid the rent for him for the first three months. Now he pays the rent himself. The house in which he lives is incomplete with no glass in the windows, which are covered by papyrus mats. He has his own room and the other housemates are people he works with.

When asked if his house mates are married he says 'no, they just bring them in', meaning that they bring in women for casual sexual encounters. He denied having engaged in any such activity, explaining that due to his long work hours he doesn't have time to 'roam about'. Additionally he says that he doesn't know much about the girls in Mputu and doesn't trust them. Because of this he hasn't 'given in yet'. In the village he reports knowing most of the girls because he has grown up with them. In town he heard a rumour that the girls are promiscuous and it is because of this that he does not trust them. He simply states, 'I want those from the village.' However, when probed further he describes how the girls in Mputu are 'hard to me on money issues' and goes on to say that they ask for much money every time they meet. He highlights the transactional demands placed on men in sexual relationships, even for those men not explicitly paying for sex. He states, 'well, for her who hasn't charged you, at the end appears to have charged you because every time she sees you she asks you this or other amount, Vaseline etc.' This appears to imply that Noah has had sexual partners in Mputu despite his original assertion that he had not. When asked again about sexual partners in the town, he states that he has had one partner and that this lasted for three months and during that time 
she asked him for a lot of money. He describes how girls in the village ask for much less.

When asked about how he made friends when he first came to the town, Noah describes how he got most of his friends from the local football club. The problem with the friends was that they took girls whom he had started to court. This happened three times. The people he wanted to be his friends were his work mates as he had to live and work with them, and therefore it was better if they were friends. The people Noah wouldn't want to be friends with are 'those from outside that cannot help you', for example rumour-mongers as well as people who can't be trusted or may cause him trouble. Noah perceives a definite difference between the friends in the village whom he grew up with and whose homes and backgrounds he is aware of, and those in Mputu whose background he does not know. He says that in the village they resolve disputes when they arise and life goes on as usual, but in the town they may do you harm and then disappear.

Despite some of the problems that Noah experienced on coming to the town, he says that he prefers life in the town because it is more sophisticated. 'Life in town is better because there are many interesting things, you learn jobs from there and also get money. While in the village, though one has friends and can roam around no one has money to buy a piece of cloth.' Although he concedes that there are ways for youth in the village to earn money, giving the examples of trading coffee, digging and growing sugar canes and vegetables, he goes on to explain that these are not reliable, while in the town you can depend on your work, it doesn't 'expire' but goes on year after year (he was fortunate to have steady employment at the time of the interview). More specifically he explains that the town work is not seasonal: 'Years go on one after the other, but for you, you can harvest your crops and they get finished and then wait for the next rain season whereas here even if it rains or whatever, I continue with my work.'

Noah summarises the difference between behaviour in the village and town by saying that people in the town are not as 'decent' as those in the village. He goes on to say that most people's behaviour is bad because they are youth, and they are the ones who exhibit bad behaviour: 'They get habits of abusing people, talking nasty words everywhere and they always think about talking such bad things. Talking obscene words and doing things which are not worthy like taking drugs, it is the youths who mostly do this.' He goes on to explain that youths in the village are less likely to do this and don't form groups in the same way as those youths in town. People in the village are less likely to get 
'spoilt' than those in town because there are not the same opportunities for socialising.

Noah's relationship with his family changed. Now that he is earning money his grandparents are relieved of the burden of looking after him. In the future he feels that his family will expect him to look after them in their old age. At the time of the interview his grandfather could not dig anymore, and so when Noah bought sugar and other things such as salt, fish and meat he took them to the family. He reports that he does not expect to go permanently back to the village, because there are no opportunities to make money there. He feels that this would let down his family as he would not be able to provide for them as he wishes and feels he is expected to. He also describes how the village is now boring for him. He says about town: 'Here I can go to attend a film, I see different people, cars, this and that, whether pleasing or not pleasing, but if you go to the village it seems as if you are in a forest without any person speaking, but here you see this one and that one...' In addition to the entertainment Noah refers to the freedom and independence that he has in town, specifically mentioning the fact that he no longer lives in the same house as relatives: 'When I am in the village staying with them [his relatives] I cannot go to attend such entertainment but here when I am independent, I can decide to go or not to go, and this also makes me feel like not going back to the village to my grandparents.'

Noah's story expresses the two main drivers of the move to the town-economics and intrigue! Although he emphasises the economic reasons for moving, he also appears fascinated by what he has heard from others about town life, and wants to see for himself. Therefore, migration may be an important component of his well-being and selfdiscovery. He considers town life more sophisticated than village life. Although he seems to miss home and the people there, he has no desire to go back permanently. However, his description of his relationship with his family and the expectations that he feels are placed on him illustrate an on-going tie. It appears that when Noah moved to the town, the shift from Noah as a boy who needed care, to a man who could and should support his family, jumped in terms both of his self-perception and of his family's perception of him. This indicates that youth migrants may undergo a double identity shift on moving to an urban setting: one rooted in migration and the change from rural to urban life, the other in life course. In Noah's case the economic opportunity of migration and the expectations (both his and his family's) that accompany this seem to have accelerated his transition to adulthood. 
Noah tries to make sense of his urban experience by relating to two main groups - firstly his colleagues at work, and secondly the football team. He understands the importance of social ties and getting on with people in his new setting. He also points out that he would not want to be friends with 'people from outside', indicating that he has a strong sense of himself as being 'inside'. However, we also get a sense of the tension that he experiences in trying to fit in while still maintaining an identity of being good and 'decent'. Noah's initial shyness about what he was actually told about life in town and also his sexual relationships may reflect his reaction to the interview situation -i.e. wanting to construct an image of himself as a person who exhibits 'good' behaviours - but it may also indicate the identity conflict he was experiencing: wanting to portray himself as a sophisticated, independent town dweller, but to also maintain a 'wholesome' identity more associated with the village. He therefore tries to dissociate himself from the more negative characteristics of the town. With regard to his family, it seems that the main identity shift they observe and that he wishes to portray to them is not that he is now an urban dweller but that he is now an adult. It is important that they perceive him as successful and able to provide for their needs, which represents a shift to an adult identity, while maintaining the identity of a 'decent' rural man free of urban vices. Thus in Noah's life we can appreciate the difficulty, whether conscious or not, of moving to a different geographical space while navigating a significant biographical identity shift.

\section{Carol $^{2}$}

Carol grew up in Nalubolo village. As a child she lived with her mother. Her father lived in a nearby village with his co-wife but he died of AIDS when she was 13. Carol was one of eight children of her father, two of whom died leaving four girls and two boys; and one of twelve children born to her mother, of whom one has died leaving four boys and seven girls. Her father worked as a mechanic, carpenter and trader. Her mother is a farmer growing and trading food crops.

Before moving to Mputu Carol had heard rumours about the town. When she was young she used to hear that there was lots of money in town and there were jobs. She thought that when she grew up she would want to go and get a job and money. She had stopped her education because there was no money to pay for school fees, but she didn't have a proper job so she wanted someone to take her to the town. She had also heard that many people in Mputu have HIV and that there were women 
that sold sex, but because she was looking for work and not for men this did not scare her.

Carol had six years of primary education in her home village, but then her mother couldn't afford for her to continue. She says that she liked school and that she was very clever, but it was the money that 'worked against' her and meant she could not continue. She considers her education to have been partially useful in preparation for life in Mputu, for example being able to speak English is useful when someone doesn't know Luganda.

She was brought to the town by a woman from the village who ran a restaurant and wanted Carol to work for her. However, she paid her only UShs.50o per day (about £o.15). She looked for another job and got one at the beauty salon where she was working at the time of interview. Although she says the money is poor she has stuck with it. The amount she is paid depends on the number of customers: 'Sometimes you could get 3,00o shillings at the end of the day and other times you get 2,5 oo. Like that. On the days that are very busy, for instance, public holidays you can end the day's work with 5,ooo shillings.' Carol reports that she found it difficult initially not having people to talk to, but that eventually she got used to the situation. She also works in a bar because she doesn't get customers for hair plaiting every day.

Carol describes how it took her a long time to make friends, because first of all she was scared of people and didn't want to talk to them. But over time she has got to know people and learnt about the area. She now has two friends: one is a waitress and one works as a cashier in a bar. Carol says that the people she would like as friends are those who can offer constructive help. She says that she wants to avoid bad characters including thieves and friends who give bad advice or introduce you to other bad people. She feels that her friends in town can offer better advice than those in the village, and also more practical help such as getting you a job. Carol points out that in town there are bad groups of people who attend discos and similar social events, but that these do not occur in the village. These groups may be marijuana takers, disco goers, prostitutes. She notes: 'In town, there are people who have good characters and others who have bad characters. In town, there are many people and at times, you find bad habits. You find everything in town. It is different from the village. Well, there are also bad habits in the village but not to the extent of that in town.' She says that she personally doesn't belong to any groups, she has her one or two friends with whom she converses and this is enough. 
Regarding relationships with men, Carol notes that although she fears contracting HIV, if you know that there is a man and he will help you (financially or with gifts), then you end up having sex with him. She says, 'you take courage because you want money', and that judging from the promiscuity in the area people in the town fear HIV a lot less than those in the village. She adds: 'What surprised me when I came here, I did not know that men buy women. I saw it here, in town. Imagine seeing someone parking the vehicle and negotiating with a woman to sell him sex, he pays and they go off. It surprised me because I heard it from here. I first heard it and then witnessed it.'

Overall, Carol concludes that the main reason for having a boyfriend is financial support. She describes how having a boyfriend in town is different from the village because he can get money easily and help you more. She also thinks that having a boyfriend in town saves you from being promiscuous while also helping to support you. In the village the seasonal nature of the crops means that it is necessary to wait for a man to provide assistance and therefore you have to look in different places trying to find money, but with men from town this is avoidable. She says that although it is possible to get support from a casual partner this is more risky.

Carol emphasises that she has not had problems with boyfriends since she arrived, however, her current boyfriend is married and he only visits periodically. She therefore has to wait a long time before getting money. Before getting into a relationship with him, about five months after she arrived, she just had casual partners. She stresses that the reason she wanted a boyfriend was to help her with financial matters and also to provide her with sexual satisfaction so that she does not have to look for sex with different men. The first time she got a casual partner she recalls being scared but he comforted her and reassured her that they were going to use condoms. He gave her UShs.10,000 in return, which was significantly more than her daily earnings. Even with her regular partner she emphasises that they always use condoms: she remarks, 'he is more scared of it [HIV] than even I am'.

Carol says that she has found adjusting to the area very hard, especially when she fails to get money. Although she is surviving she does not consider it a satisfactory life. She says that if there is work then she will stay, but if not she will move to another town, possibly Kampala. She doubts she will move back to the village because 'it involves digging and what you grow takes long to materialise'. She says that she does not know what she wants in the future and that she is still planning for it.

Carol's attitude towards relationships with men is common across the eighteen women interviewed. While she fears contracting HIV, financial 
necessity pushes her into relationships that she feels are unavoidable. All the women recognised that support from men is crucial for their wellbeing. A similar pressure exists for young women to engage in sexual relationships in the village, for example to cover school fees and luxury items (Seeley 2008). However, in the town the lack of safety nets, such as those provided by family, and the absence of subsistence agriculture, increase pressure to secure cash income for survival. Furthermore, her story suggested that she had a strategy to reduce the number of sexual partners that she had. But in the interview context it is likely that Carol would want to portray herself in a more responsible light, and possible that she was describing ideal rather than actual behaviour.

While Carol does not positively identify with any distinct group, she does point out the groups of which she is definitely not a member, and uses this to make sense of her experience and belonging in the town. She notes that she has two friends but that she is not a group member - a trait which she associates with 'bad characters'. However, she also recalls finding it very hard to adjust to life in the town, having no one to talk to when she first arrived and then being unsure who to trust.

Carol did not discuss her relationship with her home village to the same extent as Noah. Although she comes across as a strong character determined to be successful, and appears to have improved her income by finding better-paid employment, she does not talk about helping her family in the village, or seem to feel any responsibility for it. However, some female respondents did, as discussed below. Despite coming to the town, which marked a transition to independence and arguably adulthood in Noah's story, there are still strong elements of dependence in Carol's story - not on family or those in the village but on men, which contrasts sharply with Noah's narrative of independence and reciprocity. However, for Carol the shift of dependence from family to men through sexual relationships combined with a degree of independence through paid employment may represent a similar biographical shift. This highlights the gendered nature of migrant and adolescent transition experiences.

Having looked at two cases in detail we now take some of the major themes that have arisen in these cases and discuss them in the broader context of the data.

\section{Constructing 'good and evil'}

In the two stories above, we saw that both respondents wanted to distance themselves from the bad behaviour they associated with town 
life. This tension between wanting to become part of the town but not associated with its more negative aspects was an underlying theme in the identity construction common to all the youth migrants. The village was portrayed as a good, moral place, where people behaved well, were faithful to their partners and went to church regularly. This was countered with a perception of the town as full of bad people that were thieves, went to discotheques and were promiscuous. Cheney (2007: $15^{8}$ ) observes that although rural people were considered to be less 'developed' than those in the town, 'they are also an antidote for the ways that city life breaks down certain morals, norms and cultural understandings of heritage and identity'. However, looking at the description of respondent experience throughout their lives, these polarised constructions begin to break down. For example, we find that many young people had been sexually active in the village before they came to the town. Girls report being 'conditioned' by boys and men to have sex while they were still at school. Sexual encounters are reported to have occurred in the bush or on the way to collect firewood or water.

Nevertheless, the young people tried to distance themselves from the sinful activities of the town. Repeatedly respondents begin by saying that they had not had a sexual partner since they arrived in the town, only to talk about the different partners they were now involved with later in the interview. Although they were living in the town, they portrayed themselves in the interviews as good people, mirroring the good behaviour which in their narratives they accredited men and women in the village. One young man included reference to this perception when he explained why he had not migrated prior to a relative arranging a job for him: 'It's because I am not the kind of person who is so much taken up by town life for if I were, I would have gone anyhow but I told him that I wasn't leaving [the village] without having a concrete job which I was going to do. He told me there was. He told me to take myself [to the town]. I didn't leave the village until he came' (Ali 2004 int.).

Some of the respondents talked of 'bad behaviours' and identified them as a possible cause of their downfall, and described how engaging in such activities may lead to their ruin and spoil the chances they were offered by living in town: 'I avoid those people who chew drugs like marijuana, and those who puff opium, I don't like them also. And I don't like those who drink beer, for the reason that they can spoil my chances of getting money and I also get spoiled; yet I have now started getting a home' (Moses 2004 int.).

However, it seems that the reality of urban life often prevented the respondents from sticking to their image of themselves (the 
'biographical illusion' portrayed to us) and how they should behave. The new experiences of urban life present many temptations which a large proportion of town dwellers indulge in, as far as the young people could see. New arrivals therefore face something of an identity crisis - how to remain a 'good person' but also fit in socially, not to mention survive economically. For young women, as we saw in Carol's story, this survival often seemed to include engaging in sexual relationships to enable them to get support either financially or through gifts; these relationships ranged from overt sex work, to casual one-night stands, to accepting steady relationships and marriage. For men this included engaging in sexual relationships to prove their 'normalness'; although this is not unique to urban settings, the setting may encourage more risky sexual behaviour. The responses the young men and women gave seem to emphasise the bad behaviour in the town but they also tried to distance themselves from it, perhaps guarding themselves, and the interviewer, from the reality of their new lives.

When respondents were asked whether they considered themselves to be a village or town person, there was a tendency to still describe themselves as a village person despite in some cases extended time living in the town. People remain tied to the village through kinship and will often be buried on family land. Cheney (2007) described the village as 'home', connecting the individual to previous generations, and sustaining a sense of cultural identity amongst Ugandan children who move to the town.

\section{Shifting attitudes to the village: support, reciprocity and relations}

In addition to this sense of good and evil, it also became apparent that the young migrants' relationships with the village and their families undergo significant change following their move to the town, inevitably impacting on their own identity. This was particularly notable in Noah's story. This is linked not only to migration but also to the transition to adulthood.

The expectations the youth had about town life had been developed through what they had heard from people in the village: 'there was my friend who used to come to the village; he could come and tell us many possible things about the town like working, enjoying and things of the sort; so I also picked the interest of coming to town' (Moses 2004 int.); and 'when my uncle who works in Kampala as a builder came home; and talked about what they do with his colleagues at work. How they used to 
enjoy life in Kampala. There you get a picture and conclude that, it seems to be a fun place' (John 2004 int.).

The expectations of 'fun' and 'enjoyment' contrast quite sharply with the sense of responsibility that respondents actually reported. Many of them reported a shift from having family in the village support them, to feeling that they were then expected to provide for their family by sending home wages and gifts. The amount of support that they received once they had moved to the town varied significantly. Nearly all respondents had been brought to the town by someone whom they knew, usually a family member. Most had a specific job lined up before they arrived, and many had a place to stay, at least temporarily. There was a sense that moving to the town was a real transition, although few expressed this directly: they felt more productive than just living in the village digging other people's land, earning very little money, and they clearly had very high expectations.

One young woman described what was expected of her now that she lived in town: 'In the village they expect me to visit them on the festival days and buy them little things, for home use [domestic things], eee [yes] and to leave them with some little money' (Phoebe 2004 int.). However, one young man described how his on-going relationship with the village largely through his sister enabled him to finance his business in town and still utilise the opportunities offered by the village: 'My elder sister, for sure she has helped me; the way she has helped me, she used to look after my cows, she has some goats and chickens; so whenever I could get some financial problems, I could tell her to sell one of the goats and send me money to buy a basin. Or on the other hand, to sell a hen then send me money and I buy things I want; that is how she helped me up to now' (Moses 2004 int.). However, he goes on to point out that since he has been working in town his sister no longer just gives him money to help him with problems. Now if she provides him with a loan she expects him to pay it back and gives him a time limit to do so. In addition, he describes how he now feels that he has to prove to her that he is a grown-up, and can do that by supporting her because he has received support from her in the past.

Connections with the village often remain very strong, as the youth come to the town for a specific task with a relative or village member. As one young woman pointed out, this can help with many of the problems associated with moving to the town: 'I didn't suffer first as other children [youth] who come to town, they come for example looking for jobs, here at our work, one may come searching for work s/he goes on asking each and every one, "do you have some work?" (Phoebe 2004 int.). 
Despite moving to the town, all respondents had at least some remaining connection to the village, but in the majority of cases the nature of relations with people in the village had changed significantly, supporting Thorsen's (2006) emphasis on the role that rural-urban migration played in an individual's transition from youth to adulthood.

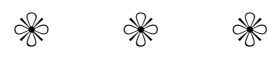

Having looked directly at the experiences of young rural-urban migrants in Uganda, what insights can we draw with regard to the impact of migration on identity? Firstly, migrants' continued contact with the rural as well as the urban means that it is difficult for them to detach themselves from either environment. The sense of historicity that Cheney (2007) brings to the migrant identity discussion helps to explain why the young people maintain a sense of belonging to a home in a rural area while residing in town. It is not that they are unable to make the mental leap between rural and urban residence, but that the sociocultural context promotes and reinforces a connection with previous generations which is often centred on the traditions of village life. It is therefore understandable that when migrants are asked whether they are urban or rural, they are often uncertain what to say.

The cases presented illustrate the on-going relationships that the young people had with their villages, but these relationships were very dynamic, changing significantly over time. Our data indicate that the experience of migration and the economic opportunities it offers accelerates the shift from dependent child to independent, economically productive adult, and this affects the view of the village and the villagers' view of them, echoing the findings of Thorsen (2006). While there may be a desire to prove that they have bettered their life through their move, they may also have internalised an urban superiority, making it difficult not to look down on the village when they return. Although urban migration may be risky, not attempting to migrate may represent a threat to their well-being as aspirations fuelled by stories of success from the town are frustrated. The awareness of this phenomenon helps to clarify why young people may migrate despite the possible hardship in the urban setting, and in some cases the apparent lack of economic gain.

One knowledge gap that we address is a consideration of the challenges to a young person's identity within the urban context. Cheney (2007) discussed this in relation to the village and Thorsen (2006) in respect to becoming an adult. Neither dealt in detail with the situation that young migrants face when they move to the town, and how 
the move promotes a shift in identity so that they can survive within the urban context. While we may consider rural/urban to be a key identity issue, this may be far from the most salient social categorisation for the respondents. Gender may be more important. The stories commonly detailed the nature of gender relations and the highly gendered nature of urban livelihoods. Alternatively it may be occupation. Respondents spoke about only being friends with people whom they worked with, and avoiding certain groups such as drop outs, sex workers, schoolgirls or drug takers. This is often in contrast to the village, where it was felt that people can be more widely trusted because you know more about them and often know about their families and upbringing.

In terms of social development policy and avoiding the potential problems of a large young urban-focused population, these findings have raised some interesting points. For example, in order to cope with the potential threats to their well-being which urban life presents, young migrants may try to dissociate themselves from risky behaviour or groups, even if they are engaged in such behaviour. The danger here is that their strategies of identification prevent them from acknowledging the risks that they face in their new environment, potentially increasing their vulnerability. Education campaigns aimed at encouraging safe sex for instance may fall on deaf ears, if young people are unwilling to identify with their new lifestyle and the opportunities and dangers it incorporates.

However, what people say in interviews may not match how they actually behave. Enosh and Buchbinder (2005) remind us that in research what the respondent says in an interview context may not provide a true picture of their subjectivity. Both the interviewer and interviewee are influenced by what the other says and does during the interview (Rubin \& Rubin 2005). The young respondents were aware of the context in which they were being interviewed, and may have given responses that they thought would be acceptable to the interviewer, who they knew was from an organisation associated with health research. Thus they may actually be more strongly identified with vulnerable groups than their responses indicate, something they preferred the interviewer not to know. Therefore from what is said interviewees may be clearly identifying with one group, while their behaviour indicates that in reality they self-categorise with another group.

Literature on rural-urban migration has increasingly focused on the blurring of these two arenas, both geographically with increasing awareness of 'peri-urban' areas, and temporally-highlighting the fluidity of migration and how migrants maintain relations with the 
home village whilst building new lives in the urban areas (Cheney 2007; Molyneux et al. 2002). Our research suggests that the rural/urban division of researchers and policy makers is not reflected in the experience of people who migrate from rural areas. Connections with the village are more than just a matter of geography or economics. By focusing on the issue of identity, we have revealed a more nuanced understanding of how young people perceive themselves and their own behaviour in this context. Migration forms an important component of youth transition to adulthood, and accelerates the economic and social developments which comprise this shift.

\section{NOTES}

1. Noah 2004 int.; all names have been changed.

2. Carol 2004 int.

\section{R E F E R E N C E S}

Bertaux-Wiame, I. 1979. 'The life history approach to the study of internal migration', Oral History 7 , 1: $26-32$.

Blum, R. 2007. 'Youth in sub-Saharan Africa', Journal of Adolescent Health 41, 3: 230-8.

Blum, R. \& K. Nelson-Mmari. 2004. 'The health of young people in a global context', Journal of Adolescent Health 35, 5: 402-18.

Boadi, K. \& M. Kuitunen. 2005. 'Environment, wealth, inequality and the burden of disease in the Accra metropolitan area, Ghana', International Journal of Environmental Health Research ${ }_{15}$, 3: 193206.

Bourdieu, P. 20oo. 'The biographical illusion', in P. Gay, J. Evans and P. Redman, eds. Identity: a reader. London: Sage, 297-303.

Buvé, A., K. Bishikwabo-Nsarhaza \& G. Mutangadora. 2002. 'The spread and effect of HIV-1 infection in sub-Saharan Africa', The Lancet 359, 9322: 2011-17.

Byerlee, D. 1974. 'Rural-urban migration in Africa: theory, policy and research implications', International Migration Review 8, 4: 543-66.

Cheney, K. 2007. Pillars of the Nation: child citizens and Ugandan national development. London: The University of Chicago Press.

Coetzee, D. \& H. Schneider. 1996. 'Urbanisation and the epidemic of sexually transmitted diseases in South Africa', Urbanisation and Health Newsletter 31: 36-41.

Englund, H. 2002. 'The village in the city, the city in the village: migrants in Lilongwe', Journal of Southern African Studies 28, 1: 137-54.

Enosh, G. \& E. Buchbinder. 2005. 'The interactive construction of narrative styles in sensitive interviews: the case of domestic violence research', Qualitative Inquiry 1 1, 4: 588-61 7 .

Erikson, E. 1968. Identity: youth and crisis. New York: Norton.

Gabriel, M. 2006. 'Youth migration and social advancement: how young people manage emerging differences between themselves and their hometown', Journal of Youth Studies 9, 1: 33-46.

Gardner, K. 1993. 'Desh-Bidesh: Sylheti images of home and away', Man 28, 1: 1-15.

Garenne, M. 2010. 'Urbanisation and child health in resource poor settings with special reference to under-five mortality in Africa', Archives of Disease in Childhood 95, 6: 464-8.

Goodenow, C. \& O. Espin. 1993. 'Identity choices in immigrant adolescent females', Adolescence 28, 109: $173-84$.

Gugler, J. 2002. 'The son of the hawk does not remain abroad: the urban-rural connection in Africa', African Studies Review 45, 1: 21-41.

Harris, J. \& M. Todaro. 1970. 'Migration, unemployment and development: a two-sector analysis', The American Economic Review 6o, 1: 126-42. 
Hart, K. 197 1. 'Migration and tribal identity among the Frafras of Ghana', Journal of Asian and African Studies 6, 1: 21-36.

Hashim, I. \& D. Thorsen. 201 1. Child Migration in Africa. London: Zed Books.

Herrin, W., J. Knight \& A. Balihuta. 20og. 'Migration and wealth accumulation in Uganda', The Journal of Real Estate Finance and Economics 39, 2: 165-79.

Hogg, M. \& D. Abrams. 1988. Social Identifications: a social psychology of intergroup relations and group processes. London: Routledge.

Jones, G. 1999. 'The same people in the same places? Socio-spatial identities and migration in youth', Sociology 33, 1: 1-22.

Katz, E. \& O. Stark. 1986. 'Labour migration and risk aversion in less developed countries', Journal of Labour Economics 4, 1: 134-49.

Kloep, M. et al. 2003. 'Peripheral visions? A cross-cultural study of rural youths' views on migration', Children's Geographies 1, 1: 91-109.

Lowe, P. \& L. Speakman. 2006. The Ageing Countryside: the growing older population of rural England. London: Age Concern England.

Miles, M. \& J. Crush. 1993. 'Personal narratives as interactive texts: collecting and interpreting migrant life-histories', The Professional Geographer 45, 1: 84-94.

Molyneux, C., V. Mung'ala-Odera, T. Harpham \& R. W. Snow. 2002. 'Maternal mobility across the rural-urban divide: empirical data from coastal Kenya', Environment and Urbanisation 14, 1: $203-17$.

Montgomery, M., R. Stren, B. Cohen \& H. Reed. 2003. Cities Transformed: demographic change and its implications in the developing world. Washington, DC: The National Academies Press.

Padilla, A. \& W. Perez. 2003. 'Acculturation, social identity, and social cognition: a new perspective', Hispanic Journal of Behavioural Sciences 25, 1: 1-21.

Rubin, H. \& I. Rubin. 2005. Qualitative Interviewing: the art of hearing data. London: Sage.

Seeley, J. 2008 'The intergenerational transmission of poverty during the AIDS epidemic in Uganda', CPRC Working Paper 110 , Chronic Poverty Research Centre, University of Manchester, available at: www.chronicpoverty.org/p/598/publication-details.php.

Thorsen, D. 2006. 'Child migrants in transit: strategies to assert new identities in rural Burkino Faso', in C. Christiansen, M. Utas \& H. Vigh, eds. Navigating Youth Generating Adulthood: social becoming in an African context. Stockholm: Elanders Gotab AB, 88-1 14 .

Van Velsen, J. 196o. 'Labour migration as a positive factor in the continuity of Tonga tribal society', Economic Development and Cultural Change 8, 3: 265-78.

Weeks, S. 1973. 'Youth and the transition to adult status: Uganda', Journal of Youth and Adolescence 2, 3 : 259-7o.

World Bank. 2008. African Development Indicators 2008/2009. Washington, DC: World Bank.

\section{Interviews}

Ali, 8.7.2004. Age unknown, male, rural-urban migrant.

Carol, 27.9.2004. 25 years old, female, rural-urban migrant.

John, 6.9.2004. 16 years old, male, rural-urban migrant.

Moses, 23.8.2004. 20 years old, male, rural-urban migrant.

Noah, 29.7.2004. 19 years old, male, rural-urban migrant.

Phoebe, 23.8.2004. 18 years old, female, rural-urban migrant. 